\title{
Peningkatan Keaktifan Belajar dan Hasil Belajar Siswa Melalui Model Pembelajaran Numbered Head Together dengan Media Mind Mapping Pada Mata Pelajaran Ekonomi Kelas X IPS 1 SMA Negeri 1 Kerinci
}

\author{
Eka Apriya Dewi \\ SMA Negeri 1 Kerinci \\ Correspondence email: ekaapriyadewi17@gmail.com
}

\begin{abstract}
Abstrak. Penelitian ini bernama Penelitian Tindakan kelas (PTK). Selama kegiatan Belajar mengajar keaktifan siswa dan hasil belajar siswa masih rendah. Oleh karena itu penulis mencoba untuk meningkatkan keaktifan dan hasil belajar siswa dengan menerapkan model pembelajaran Kooperatif Numbered Head Together dengan Media Mind Mapping Subjek penelitian adalah siswa kelas X IPS 1 SMA Negeri 1 Kerinci, Manfaat dari penelitian ini agar siswa mampu memahami konsep materi ekonomi dengan baik dan dapat berperan aktif selama kegiatan belajar mengajar. Peneliti dibantu oleh rekan sesama guru mata Pelajaran Ekonomi yang berperan sebagai Kolaborator dalam kegiatan belajar mengajar. Penelitian dilakukan sebanyak dua siklus dimana setiap siklus terdiri dari empat tahapan yakni (a) Perencanaan (b) Pelaksanaan (c) Obsevasi (d) Refleksi. Hasil analisis data menunjukkan bahwa Hasil belajar dan keaktifan siswa setelah diterapkan model pembelajaran Numbered Head Together dengan Media Mind Mapping mengalami peningkatan yang signifikan. ketuntasan hasil belajar ekonomi siswa pada pra siklus dengan nilai rata-rata 50 dengan persentase $42 \%$, Setelah dilaksanakan tindakan pada siklus I capaian rata-rata nilai meningkat menjadi 71 dengan persentase $67 \%$, pada siklus II terjadi peningkatan yang signifikan dengan capaian rata-rata nilai 78 dengan persentase 76\% Sedangkan keaktifan belajar siswa pada siklus 1 adalah 65,55\% sedangkan di siklus 2 meningkat menjadi 79,36\% hal ini memberikan gambaran bahwa dengan menerapkan model pembelajaran Kooperatif Numbered Head Together dengan media Mind Mapping mampu meningkatkan hasil belajar dan keaktifan belajar siswa Oleh karena itu disarankan kepada guru Ekonomi agar menggunakan model pembelajaran Numbered Head Together dengan Media Mind Mapping sebagai salah satu solusi untuk mengatasi permasalahan siswa dikelas khususnya pada materi Pelaku Ekonomi
\end{abstract}

Kata Kunci: Numbered Head Together; mind Mapping; keaktifan belajar; hasil belajar

Abstract. This research was a classroom action research. It was figure out that during the learning and teaching process the student's activeness and achievement were still low. Therefore, this resarch was conducted to solve the problem by implementing Cooperative Number Head Together by using Mind Mapping media. The rersearch participant was the students at grade XIPS 1 of SMAN 1 Kerinci. The objective of the reserasch was to improve the student's comprehension on economics concept and activeness during the learning and teaching process. The collaborator of the research was the teacher who taught the same subject. The study was conducted in two cycles consisted of four stages;(a) planning, (b)action, (c) observation (d) reflection. The analysis result showed that there was significant improvement on the student's achievement and activeness after Cooperative Number Head Together by using Mind Mapping Media was applied. The student's average score in Pre cycle was 50 (42\%). Then, in cycle 1 the score was 71 (67\%), in cycle 2 it improved significantly to 78 (76\%). In addition, the student's activeness in cycle 1 was $65,55 \%$, and in the second cycle it improved to 79,36\%. Based on the data, it concluded that the implementation of Cooperative Number Head together by using Mind Mapping Media improved the student's achievement and activeness significantly. Therefore, it was suggested to Economic Teacher to apply the method as the alternative solution to the student's learning problem especially on Economic Agent Subject.

Keywords: Cooperative Number Head Together; Mind mapping; Learning Activeness; Learning Achievement

\section{PENDAHULUAN}

Mata pelajaran ekonomi berfungsi mengembangkan kemampuan siswa untuk berekonomi, dengan cara mengenal berbagai kenyataan dan peristiwa ekonomi, memahami konsep dan teori serta berlatih dalam memecahkan masalah ekonomi yang terjadi di lingkungan masyarakat.

Dalam proses pembelajaran guru merupakan orang yang memiliki peranan penting dalam membantu siswa untuk mencapai hasil belajar yang baik, model pembelajaran yang digunakan dalam memberikan materi kepada siswa merupakan hal yang sangat penting agar tujuan pembelajaran yang dilaksanakan tercapai.

Menurut Winatapura dalam Sugiyanto (2010) model pembelajaran merupakan kerangka konseptual yang melukiskan dua prosedur yang sistematis dalam mengorganisasikan pengalaman belajar untuk mencapai tujuan belajar tertentu, dan berfungsi sebagai pedoman bagi para perancang pembelajaran dan para pengajar dalam merencanakan dan melaksanakan aktivitas pembelajaran. Kemampuan yang diharapkan dapat dimiliki peserta didik ditentukan oleh kerelevanan penggunaan suatu model pembelajaran yang sesuai dengan tujuan.

Peneliti telah melaksanakan observasi awal saat Kegiatan Belajar Mengajar (KBM) berlangsung di kelas $X$ IPS 1 SMA Negeri 1 Kerinci berikut pemaparannya. Keaktifan siswa untuk belajar ekonomi masih rendah, 
hal tersebut ditunjukkan dalam perilaku mereka ketika mengikuti pembelajaran ekonomi ada beberapa siswa yang ribut saat proses pembelajaran, siswa, kurang aktif dalam proses pembelajaran karena hanya beberapa siswa yang berani mengemukakan pendapatnya ataupun memberanikan diri menanyakan materi yang belum dipahami, ada beberapa siswa tidak memperhatikan guru pada saat menyampaikan materi pembelajaran karena penyampaian materi pembelajaran dengan metode ceramah, sebagian besar siswa kurang aktif dalam proses pembelajaran dan beberapa siswa sibuk dengan aktivitasnya sendiri. Hal ini berakibat pada hasil belajar siswa yang kurang memuaskan.

Salah satu alternatif yang dapat ditempuh untuk meningkatkan hasil belajar siswa adalah melalui kreativitas yang dimiliki guru dalam memilih model pembelajaran pada saat kegiatan belajar berlangsung. Berdasarkan permasalahan di atas peneliti ingin mencoba menerapkan model pembelajaran Kooperatif numbered head together (NHT) sebagai usaha untuk memperbaiki keaktifan siswa dalam belajar dan hasil belajar siswa kelas X IPS 1 .

Arends dalam (Agus Suprijono, 2012) menyatakan model pembelajaran mengacu pada pendekatan yang akan digunakan, termasuk di dalamnya tujuan-tujuan pembelajaran, tahap-tahap dalam kegiatan pembelajaran, lingkungan pembelajaran, dan pengelolaan kelas. Oleh karena itu dalam pembelajaran guru dan siswa diharapkan mampu untuk bersama-sama menjadi pelaku demi terlaksananya tujuan pembelajaran.

\section{Keaktifan Siswa}

Proses pembelajaran pada hakekatnya merupakan proses interaksi antara guru dengan siswa yang didalammya berisi aktivitas peserta didik melalui berbagai interaksi dan pengalaman belajar yang dialami oleh keduanya. Menurut Sardiman, (2001) macam aktivitas siswa dalam proses pembelajaran terbagi menjadi dua bagian yaitu aktifitas fisik dan aktifitas psikis.

Belajar yang berhasil harus melalui berbagai macam aktivitas, baik aktivitas fisik maupun psikis. Aktivitas fisik adalah siswa giat aktif dengan anggota badan, membuat sesuatu, bermain maupun bekerja, ia tidak hanya duduk dan mendengarkan, melihat atau hanya pasif. Siswa sedang melakukan aktifitas psikis jika daya jiwanya bekerja sebanyak-banyaknya atau banyak berfungsi dalam rangka pembelajaran. Pentingnya keaktifan siswa dalam pembelajaran menurut Mulyasa (2005), pembelajaran dikatakan berhasil dan berkualitas apabila seluruhnya atau setidak-tidaknya sebagian peserta didik terlibat secara aktif, baik fisik mental maupun sosial dalam proses pembelajaran.

Salah satu penilaian proses pembelajaran adalah melihat sejauhmana keaktifan siswa dalam mengikuti proses belajar mengajar. Nana Sudjana (2004) menyatakan keaktifan siswa dapat dilihat dalam hal: (1).
Turut serta dalam melaksanakan tugas belajarnya,(2). Terlibat dalam pemecahan masalah, (3). Bertanya kepada siswa lain atau guru apabila tidak memahami persoalan yang dihadapinya,(4). Berusaha mencari berbagai informasi yang diperlukan untuk pemecahan masalah, (5). Melaksanakan diskusi kelompok sesuai dengan petunjuk guru, (6). Menilai kemampuan dirinya dan hasil-hasil yang diperolehnya, (7). Melatih diri dalam memecahkan soal atau masalah yang sejenis.(8). Kesempatan menggunakan atau menerapkan apa yang diperoleh dalam menyelesaikan tugas atau persoalan yang dihadapinya. Berdasarkan uraian di atas dapat disimpulkan keaktifan siswa dapat dilihat dari berbagai hal seperti memperhatikan (Visual activities), mendengarkan, berdiskusi, kesiapan siswa, bertanya keberanian siswa memecahkan soal (mental activities)/

\section{Hasil Belajar}

Menurut Oemar Hamalik (2001), "Hasil belajar adalah bila seseorang telah belajar akan terjadi perubahan tingkah laku pada orang tersebut, misalnya dari tidak tahu menjadi tahu, dan dari tidak mengerti menjadi mengerti”. Selanjutnya Dimyati dan Mudjiono (2009) mengemukakan bahwa hasil belajar adalah hasil dari suatu interaksi tindak belajar dan tindak mengajar. Dari sisi guru, tindakan mengajar diakhiri dengan proses evaluasi hasil belajar, dari sisi siswa hasil belajar merupakan puncak proses belajar.

Berdasarkan Teori Taksonomi Benjamin S. Bloom dalam (Abdurrahman, 2003), Ada tiga ranah hasil belajar yaitu kognitif, afektif dan psikomotorik. Hasil belajar kognitif yaitu, hasil belajar yang berdasarkan pengalaman, hasil belajar yang afektif yaitu dengan cara mengenal dengan cara merasakan, dan hasil belajar psikomotorik yaitu hasil belajar berdasarkan sikap atau aktivitas anak didik tersebut. Sehingga dapat disimpulkan bahwa hasil belajar merupakan pencapaian bentuk perubahan perilaku yang cenderung menetap dari ranah kognitif, afektif, dan psikomotorik.

\section{Pembelajaran Kooperatif}

Model pembelajaran kooperatif adalah rangkaian kegiatan belajar yang dilakukan oleh siswa dalam kelompok-kelompok tertentu untuk mencapai tujuan pembelajaran yang telah dirumuskan. Agus Suprijono (2009) mengemukakan bahwa pembelajaran kooperatif adalah konsep yang lebih luas meliputi semua jenis kerja kelompok termasuk bentuk-bentuk yang lebih dipimpin oleh guru atau diarahkan oleh guru. Secara umum pembelajaran kooperatif dianggap lebih diarahkan oleh guru, dimana guru menetapkan tugas dan pertanyaanpertanyaan serta menyediakan bahan-bahan dan informasi yang dirancang untuk membantu siswa menyelesaikan masalah yang dimaksudkan.

Slavin dalam Isjoni (2009) Mengemukakan pembelajaran kooperatif adalah suatu model pembelajaran dimana siswa belajar dan bekerja dalam 
kelompok-kelompok kecil secara kolaboratif yang anggotanya 5 orang dengan struktur kelompok heterogen. Sedangkan menurut Sunal dan Hans dalam Isjoni (2009) mengemukakan bahwa pembelajaran kooperatif merupakan suatu cara pendekatan atau serangkaian strategi yang khusus dirancang untuk memberi dorongan kepada siswa agar bekerja sama selama proses pembelajaran. Selanjutnya Stahl dalam Isjoni (2009) menyatakan pembelajaran kooperatif dapat meningkatkan belajar siswa lebih baik dan meningkatkan sikap saling tolong-menolong dalam perilaku sosial.

\section{Kooperatif Numbered Head Together (NHT)}

Dalam model pembelajaran Kooperatif numbered head together (NHT), hal yang ingin disampaikan adalah bagaimana siswa mampu menerima berbagai pendapat yang diterima dan disampaikan oleh orang atau kelompok lain, kemudian menganalisisnya bersama, sehingga memunculkan pendapat yang paling ideal (Hamid, 2011).

Dari penjelasan tersebut dapat diketahui bahwa dengan menerapkan model pembelajaran kooperatif numbered head together (NHT), selain dapat mempermudah siswa dalam mempelajari materi Ekonomi, juga dapat meningkatkan kerjasama diantara siswa secara berkelompok.

Pelaksanaan prinsip dasar pokok sistem pembelajaran kooperatif dengan benar akan memungkinkan guru mengelola kelas dengan lebih efektif (Rusman, 2011). Model pembelajaran kooperatif merupakan suatu model pembelajaran yang mengutamakan adanya kelompok-kelompok. Setiap siswa yang ada dalam kelompok mempunyai tingkat kemampuan yang berbeda-beda dan jika memungkinkan anggota kelompok berasal dari ras, budaya, suku, yang berbeda serta memperhatikan kesetaraan gender. Proses pembelajaran dengan model pembelajaran kooperatif, siswa didorong untuk bekerja sama pada suatu tugas bersama dan mereka harus mengkoordinasikan usahanya untuk menyelesaikan tugas yang diberikan guru.

Salah satu tipe model pembelajaran kooperatif adalah numbered head together (NHT). Pembelajaran kooperatif numbered head together (NHT) merupakan salah satu tipe pembelajaran kooperatif yang menekankan pada struktur khusus yang dirancang untuk memengaruhi pola interaksi siswa dan memiliki tujuan untuk meningkatkan penguasaan akademik (Fathurrohman, 2012).

Pendapat ini dipertegas oleh Trianto (2012) bahwa kooperatif numbered head together (NHT) atau penomoran berpikir bersama adalah merupakan jenis pembelajaran kooperatif yang dirancang untuk memengaruhi pola interaksi siswa dan sebagai alternatif terhadap struktur kelas tradisional.

Numbered Head Together (NHT) dilakukan dengan cara setiap siswa diberi nomor dan dibuat suatu kelompok, kemudian secara acak, guru memanggil nomor dari siswa (Hamdani, 2011). Tujuan dari pembelajaran ini adalah memberi kesempatan kepada siswa untuk saling berbagi gagasan dan mempertimbangkan jawaban yang paling tepat (Huda, 2011).

Langkah-langkah Model Pembelajaran Kooperatif numbered head together (NHT) menurut Trianto (2012) berpendapat bahwa dalam mengajukan pertanyaan kepada seluruh kelas, guru menggunakan struktur empat fase sebagai sintaks numbered head together (NHT):

a. Fase 1: Penomoran, Guru membagi siswa ke dalam kelompok 3-5 orang dan kepada setiap anggota kelompok diberi nomor antara 1 sampai 5.

b. Fase 2: Mengajukan pertanyaan, Guru mengajukan pertanyaan kepada siswa.

c. Fase 3: Berpikir bersama Siswa menyatukan pendapatnya terhadap jawaban pertanyaan dan meyakinkan tiap anggota dalam timnya mengetahui jawaban tim.

d. Fase4: Menjawab Guru memanggil suatu nomor tertentu, kemudian siswa yang nomornya sesuai mengangkat tangannya dan mencoba untuk menjawab pertanyaan untuk seluruh kelas.

\section{METODE}

\section{Jenis dan Desain Penelitian}

Jenis penelitian yang digunakan adalah jenis penelitian tindakan kelas. Penelitian tindakan kelas adalah suatu rangkaian langkah yang terdiri atas empat tahap, yakni perencanaan, tindakan, pengamatan dan refleksi (Kunandar, 2008).

\section{Waktu Penelitian}

Waktu penelitian dilaksanakan pada bulan Januari s.d Maret 2020, pada semester genap tahun pelajaran 2019/2020.

\section{Tempat Penelitian}

Penelitian ini dilaksanakan di SMA Negeri 1 Kerinci yang terletak di Jalan Hiang Lestari Kecamatan Sitinjau laut kabupaten Kerinci.

\section{Subjek Penelitian}

Subjek Penelitian ini adalah siswa kelas X IPS 1 SMA Negeri 1 Kerinci yang berjumlah 21 Orang yang terdiri dari 9 orang perempuan dan 12 Orang Laki-laki.

\section{Jenis Tindakan}

\section{a. Tahap perencanaan (Planing)}

Peneliti melakukan analisis kurikulum untuk mengetahui kompetensi dasar sesuai dengan konsep pembelajaran memecahkan masalah yang akan di sampaikan kepada siswa dalam pembelajaran. Membuat RPP yang berdasarkan silabus pelajaran yang mengacu ke tindakan, merancang strategi penerapan model pembelajatan kooperatif Numbered 
Head Together dengan media Mind Mapping.

b. Tahap Pelaksanaan Tindakan (Acting)

Pada tahap pelaksanaan tindakan, peneliti melaksanakan pembelajaran sesuai yang telah didesain dalam Rencana Pelaksanaan Pembelajaran (RPP).

C. Tahap Pengamatan (Observing)

Pada kegiatan Observasi dilaksanakan berdampingan selama proses pelajaran berlangsung. Observasi dilakukan untuk mengamati kegiatan belajar mengajar, keaktifan siswa, kemampuan interaksi siswa serta berkomunikasi dalam menyelesaikan tugas dan penyajian tugas kelompok, Pengamatan yang dilakukan peneliti disini untuk mengetahui data kemajuan prestasi belajar siswa.

d. Tahap Refleksi

Mengkaji ulang tindakan yang telah dilakukan terhadap subjek penelitian. Memperbaiki pelaksanaan tindakan sesuai hasil evaluasi yang dituangkan pada rencana tindakan pada siklus berikutnya, kegiatan ini dilakukan oleh kolaborator dengan peneliti untuk mendiskusikan tindakan yang telah dilakukan. Jika hasil refleksi terdapat kekurangan dan masalah, maka dapat dilakukan perbaikan pada siklus berikutnya.

\section{Teknik dan Instrumen Pengumpulan Data}

Sesuai dengan sumber data yang digunakan dalam penelitian ini, maka teknik pengumpulan data yang digunakan antara lain melalui (a). Observasi Instrumen yang digunakan adalah lembar observasi yang akan digunakan untuk melaksanakan pengamatan dalam pelaksanaan dan perkembangan pembelajaran ekonomi yang dilakukan oleh guru dan siswa. (b) Teknik Evaluasi/ Tes, teknik ini digunakan untuk mengetahui perkembangan dan keberhasilan pelaksanaan tindakan. Adapun tes yang diberikan berupa tes tertulis dalam bentuk latihan-latihan soal dan tes akhir untuk mengetahui hasil belajar siswa.(c). Dokumentasi, teknik ini digunakan untuk mendokumentasikan pelaksanaan penelitian berupa gambar-gambar untuk mendukung terpenuhinya sumber data yang meliputi aktivitas guru saat mengajar dan aktivitas siswa saat pembelajaran dan diskusi.

\section{Teknik analisis data}

Teknik analisis data yang digunakan adalah analisis deskriptif, yaitu memaparkan data hasil pengamatan tiap akhir siklus. Tujuannya untuk melihat tingkat ketuntasan belajar siswa baik secara individual maupun klasikal. Adapun rumus yang digunakan adalah sebagai berikut:

a) Ketuntasan individual dengan rumus:

$$
\mathrm{S}=\frac{R}{\mathbb{N}} \times 100 \%
$$

$\mathrm{S}=$ Persentase ketuntasan individual

$\mathrm{R}=$ Skor yang diperoleh siswa

$\mathrm{N}=$ Skor maksimum tes Ketuntasan individual Tercapai jika $>75 \%$

b) Ketuntasan belajar klasikal dengan rumus:

$\mathrm{P}=\frac{R}{T} \times 100 \%$

Keterangan:

$\mathrm{P}=$ persentase ketuntasan klasikal

$\mathrm{R}=$ jumlah siswa yang tuntas

$\mathrm{T}=$ jumlah seluruh siswa Ketuntasan klasikal tercapai jika $>75 \%$

c) Teknik analisis presentase keaktifan siswa

Penilaian Aktivitas Belajar dilakukan dengan memberikan skor (0-2) berdasarkan kriteria yang sudah ditentukan sebelumnya. Skor ditentukan berdasarkan kemunculan indikator yang diperoleh dari hasil observasi selama proses pembelajaran kemudian di hitung dengan rumus sebagai berikut:

$$
\%(\text { Persentase })=\frac{\text { Jumlah Skor Siswa }}{\text { Skor Maksimal }} \times 100
$$

Instrumen lembar observasi berisi indikatorindikator dari aktivitas belajar siswa yang diamati pada saat kegiatan penelitian berlangsung. Aspek yang akan diamati dalam penelitian ini adalah kegiatan yang berhubungan dengan aktivitas belajar ekonomi, yaitu:

\begin{tabular}{|c|c|c|}
\hline No. & Indikator yang diamati & Jenis Aktivias \\
\hline 1 & $\begin{array}{l}\text { Memperhatikan saat guru } \\
\text { menerangkan }\end{array}$ & Visual Activity \\
\hline 2 & Membaca materi pelajaran & \\
\hline 3 & $\begin{array}{l}\text { Bertanya kepada guru atau } \\
\text { teman dalam proses } \\
\text { pembelajaran dan diskusi }\end{array}$ & Oral Activity \\
\hline 4 & $\begin{array}{l}\text { Mendengarkan penjelasan guru } \\
\text { dan diskusi kelompok }\end{array}$ & Listening Activity \\
\hline 5 & $\begin{array}{l}\text { Mengerjakan tugas kelompok } \\
\text { yang diberikan guru }\end{array}$ & \\
\hline 6 & $\begin{array}{l}\text { Mencatat materi pelajaran yang } \\
\text { telah dijelaskan }\end{array}$ & Writing Activity \\
\hline 7 & $\begin{array}{lrr}\text { Berdiskusi } & \text { dengan } & \text { sesama } \\
\text { anggota } & \text { kelompok } & \text { untuk } \\
\text { memecahkan masalah } & \end{array}$ & Mental Activity \\
\hline 8 & $\begin{array}{l}\text { Mengerjakan tugas secara } \\
\text { individu }\end{array}$ & \\
\hline 9 & $\begin{array}{l}\text { Membantu sesama anggota } \\
\text { untuk menguasai materi } \\
\text { pelajaran }\end{array}$ & Emotional NHT \\
\hline 10 & $\begin{array}{l}\text { Bersemangat dalam mengikuti } \\
\text { Pembelajaran }\end{array}$ & \\
\hline
\end{tabular}

Tabel 1. Pedoman Indikator Observasi

Keterangan: 


\section{Kriteria Keberhasilan}

Penelitian tindakan kelas ini dikatakan berhasil apabila dalam penggunaan model Pembelajaran Kooperatif Numbered Head Together (NHT) dapat meningkatkan keaktifan dan hasil belajar siswa. Peneliti merumuskan indikator keberhasilan dalam penelitian ini adalah:

1. Penelitian dengan menggunakan model pembelajaran Kooperatif numbered head together (NHT) ini berhasil apabila ada peningkatan keaktifan belajar ekonomi dalam kegiatan pembelajaran di kelas dari siklus satu ke siklus dua. Tujuan pembelajaran dengan metode ini dapat dikatakan berhasil dan berkualitas apabila aktivitas belajar siswa mampu mencapai minimal $75 \%$ siswa aktif saat pembelajaran di kelas.

2 Penelitian dengan menggunakan model pembelajaran Kooperatif numbered head together (NHT) ini berhasil dan berkualitas apabila ada peningkatan hasil belajar dan mencapai tingkat keberhasilan siswa dengan minimal $75 \%$ siswa mencapai KKM yang telah ditentukan oleh sekolah sebesar 70 .

\section{HASIL DAN PEMBAHASAN Deskripsi Hasil Penelitian}

Penelitian tindakan kelas ini dilakukan pada semester Genap dengan materi pembelajaran Masalah Ekonomi dan pelaku kegiatan ekonomi. Proses penelitian dilakukan dalam dua siklus yang masingmasing siklus terdiri dari empat tahap, yaitu: (1) perencanaan tindakan, (2) pelaksanaan tindakan, (3) observasi tindakan (4) analisis dan refleksi tindakan.

\section{Pra Siklus}

Pelaksanaan pembelajaran pra siklus adalah pembelajaran yang berpusat pada guru, dimana guru sebagai pusat informasi, guru menggunakan metode ceramah yang diselingi demonstrasi dan tanya jawab dalam proses pembelajaran. Guru mengamati keaktifan siswa dengan lembar observasi dengan enam indikator keaktifan. Hasil observasi menunjukkan bahwa indikator pertama yaitu Visual Activity baru mencapai kriteria cukup aktif dengan persentase capaian 33,33\%, aktif 66,67\%. indikator ke dua Oral Activity dengan kriteria cukup aktif $52,38 \%$ dan kriteria aktif $42,62 \%$, indikator ke tiga Listening Activity mencapai 19,04\% pada kriteria tidak aktif, 47,62\% pada kriteria cukup Aktif, dan $33,33 \%$ dengan kriteria aktif. Indikator ke empat Writing Activity capaian keaktifan siswa $19,04 \%$ tidak aktif, $38,09 \%$ cukup aktif, dan 42,86\% aktif, indikator ke lima Mental Activity sebesar 4,76\% tidak aktif, 38,09\% cukup aktif, dan $57,14 \%$ aktif. Indikator ke enam Emotional menggunakan metode ceramah $4,76 \%$ tidak aktif, $42,86 \%$ cukup aktif, dan 52,38\% aktif.

Berdasarkan data di atas capaian rata-rata siswa yang aktif baru mencapai 50\%. Dari data tersebut dapat disimpulkan bahwa keaktifan siswa yang dilihat dari enam indikator masih rendah hal ini ditunjukkan bahwa keaktifan belum mencapai $\geq 75 \%$ dari skor maksimal atau belum seluruhnya siswa aktif dalam proses pembelajaran.

\section{Siklus I}

Pada tahap perencanaan, diadakan pembagian kelompok terlebih dahulu. Selanjutnya peneliti memberikan gambaran kepada siswa mengenai model pembelajaran yang akan dilakukan yaitu kooperatif numbered head together dengan media mind mapping. Kegiatan inti dimulai dengan siswa diminta untuk melihat tayangan sebuah video yang berkaitan dengan materi masalah ekonomi dan cara mengatasinya. Setelah peneliti memperlihatkan video peserta didik diarahkan kepada materi yang akan dipelajari, agar muncul keingintahuan yang besar yang ditandai dengan antusiasme peserta didik dalam bertanya.

Peneliti lalu membagi siswa menjadi 4 kelompok dimana setiap kelompok terdiri dari 5-6 siswa, untuk pembagian kelompoknya peneliti melihat dari nilai pre test mata pelajaran ekonomi. Setiap kelompok mengumpulkan data atau informasi dengan membaca buku ekonomi dan mencari referensi dari sumber lainnya (internet, artikel, jurnal) yang dapat mendukung pemahaman mengenai materi yang dipelajari. Setelah itu siswa dengan bimbingan guru menggunakan data atau informasi yang dikumpulkan baik dari buku maupun sumber belajar (artikel, internet) untuk menjawab pertanyaan yang telah dirumuskan, untuk disajikan dalam bentuk mind mapping.

Pengamatan dilakukan untuk mengamati keaktifan siswa berdasarkan lembar observasi data observasi pada siklus ini dapat dilihat pada tabel di bawah ini :

Tabel 2. Hasil Perhitungan Persentase Aktivitas Belajar Siklus I

\begin{tabular}{|c|c|c|c|}
\hline Indikator Aktivitas Belajar & Kategori & Persentase & Jumlah Siswa \\
\hline \multirow[t]{3}{*}{ Membaca materi pelajaran } & Tidak aktif & $0 \%$ & 0 \\
\hline & Cukup aktif & $23,81 \%$ & 5 \\
\hline & Aktif & $76,19 \%$ & 16 \\
\hline \multirow{3}{*}{ Membuat pertanyaan/ menjawab pertanyaan dari guru atau teman } & Tidak aktif & $0 \%$ & 0 \\
\hline & Cukup aktif & $42,86 \%$ & 9 \\
\hline & Aktif & 60 & 12 \\
\hline \multirow{3}{*}{ Mendengarkan penjelasan guru saat pembelajaran } & Tidak aktif & 9,52 & 2 \\
\hline & Cukup aktif & 38,09 & 8 \\
\hline & Aktif & 52,38 & 11 \\
\hline Mencatat materi pelajaran yang telah disampaikanguru & Tidak aktif & $4,76 \%$ & 1 \\
\hline
\end{tabular}


Eka Apriya Dewi, Peningkatan Keaktifan Belajar dan Hasil Belajar Siswa Melalui Model Pembelajaran Numbered Head Together dengan Media Mind Mapping Pada Mata Pelajaran Ekonomi Kelas X IPS 1 SMA Negeri 1 Kerinci

\begin{tabular}{|c|c|c|c|}
\hline & Cukup aktif & $33,33 \%$ & 7 \\
\hline & Aktif & $61,90 \%$ & 13 \\
\hline \multirow[t]{3}{*}{ Bekerja sama dengan teman sekelompok } & Tidak aktif & $0 \%$ & 0 \\
\hline & Cukup aktif & $28,57 \%$ & 6 \\
\hline & Aktif & 71,42 & 15 \\
\hline \multirow{3}{*}{$\begin{array}{l}\text { Antusias dalam mengikuti pembelajaran dengan menggunakan model } \\
\text { pembelajaran numbered head together dengan media mindmapping. }\end{array}$} & Tidak aktif & 4,76 & 1 \\
\hline & Cukup aktif & 23,81 & 5 \\
\hline & Aktif & 71,42 & 15 \\
\hline Rata - rata indikator aktivitas & Siswa Aktif & 65,55 & \\
\hline
\end{tabular}

Berdasarkan data di atas dapat diketahui dari indikator aktivitas, siswa yang aktif Visual Activity $76,19 \%$ atau 16 orang dari 21 siswa aktif, Oral Activity $60 \%$ atau 12 orang dari 21 siswa aktif, Listening Activity $52,38 \%$ atau 11 orang dari 21 siswa aktif, Writing Activity 61,90\% atau 13 orang dari 21 siswa aktif, Mental Activity 71,42\% atau 15 siswa aktif dari 21 orang siswa dan. Emotional (antusias dalam mengikuti pembelajaran yang berlangsung menggunakan model pembelajaran kooperatif numbered head together dengan media mind mapping. $71,42 \%$ atau 15 orang dari 21 siswa aktif)

Prestasi Belajar Ekonomi pada siklus I diperoleh dari soal post test yang dilakukan pada akhir siklus I. Hasil Belajar Ekonomi siklus I dapat dilihat pada tabel berikut ini:

Tabel 3. Hasil post test Siklus I

\begin{tabular}{lcc}
\hline No & Frekuensi & Post Test \\
\hline 1 & 1 & 90 \\
2 & 1 & 85 \\
3 & 5 & 80 \\
4 & 4 & 75 \\
5 & 3 & 70 \\
6 & 2 & 65 \\
7 & 2 & 60 \\
8 & 2 & 55 \\
9 & 1 & 50 \\
\multicolumn{2}{c}{ Nilai Rata-Rata N $=21$} & $\mathbf{7 1}$ \\
\hline
\end{tabular}

Tabel 4. Siswa yang sudah dan belum mencapai KKM siklus I

\begin{tabular}{ccccc}
\hline \multirow{2}{*}{ Keterangan } & \multicolumn{2}{c}{ Jumlah siswa } & \multicolumn{2}{c}{ Persentase } \\
\cline { 2 - 5 } & $<70$ & $>70$ & $<70$ & $>70$ \\
\hline Post Test & 7 & 14 & $33 \%$ & $67 \%$ \\
\hline
\end{tabular}

Berdasarkan data pada kedua tabel di atas dapat dilihat bahwa rata-rata nilai post test akhir siklus I adalah 71 , dengan persentase $67 \%$ hal ini belum menunjukkan keberhasilan, karena tindakan ini dikatakan berhasil apabila ada peningkatan prestasi belajar siswa minimal $75 \%$ siswa mencapai KKM yang telah ditentukan oleh sekolah sebesar 70 .

Dari data di atas dapat disimpulkan bahwa aktivitas belajar dan hasil belajar siswa pada siklus I belum mencapai kriteria minimal yaitu $75 \%$. Secara keseluruhan, persentase rata-rata aktivitas belajar ekonomi pada siklus I sebesar $65,55 \%$ dan rata-rata capaian hasil belajar baru mencapai $67 \%$ masih berada di bawah kriteria keberhasilan tindakan yaitu sebesar $75 \%$ sehingga belum bisa dikatakan berhasil, perlu dilakukan tindakan pada siklus berikutnya.

\section{Siklus II}

Aktivitas Belajar siklus II dianalisis berdasarkan data yang diperoleh dari lembar observasi Aktivitas Belajar yang dilakukan selama proses pembelajaran berlangsung. Penilaian Aktivitas Belajar dilakukan dengan memberikan skor (0-2) berdasarkan kriteria yang sudah ditentukan sebelumnya. Skor ditentukan berdasarkan kemunculan indikator yang diperoleh dari hasil observasi selama proses pembelajaran.

Hasil Perhitungan Persentase Aktivitas Belajar Siklus II dapat dilihat pada tabel di bawah ini:

Tabel 5. Hasil Perhitungan Persentase Aktivitas Belajar Siklus II

\begin{tabular}{|c|c|c|c|}
\hline Indikator Aktivitas Belajar & Kategori & Persentase & Jumlah Siswa \\
\hline \multirow[t]{3}{*}{ Membaca materi pelajaran } & Tidak aktif & $0 \%$ & 0 \\
\hline & Cukup aktif & $19,04 \%$ & 4 \\
\hline & Aktif & $80,95 \%$ & 17 \\
\hline \multirow{3}{*}{$\begin{array}{l}\text { Membuat pertanyaan/ menjawab pertanyaan dari guru atau } \\
\text { teman }\end{array}$} & Tidak aktif & $0 \%$ & 0 \\
\hline & Cukup aktif & $23,81 \%$ & 5 \\
\hline & Aktif & $76,19 \%$ & 16 \\
\hline \multirow[t]{3}{*}{ Mendengarkan penjelasan guru saat pembelajaran } & Tidak aktif & $0 \%$ & 0 \\
\hline & Cukup aktif & $23,81 \%$ & 5 \\
\hline & Aktif & $76,19 \%$ & 16 \\
\hline \multirow[t]{3}{*}{ Mencatat materi pelajaran yang telah disampaikan guru } & Tidak aktif & $0 \%$ & 0 \\
\hline & Cukup aktif & $19,05 \%$ & 4 \\
\hline & Aktif & $80,95 \%$ & 17 \\
\hline Bekerja sama dengan teman sekelompok & Tidak aktif & $0 \%$ & 0 \\
\hline
\end{tabular}


Eka Apriya Dewi, Peningkatan Keaktifan Belajar dan Hasil Belajar Siswa Melalui Model Pembelajaran Numbered Head Together dengan Media Mind Mapping Pada Mata Pelajaran Ekonomi Kelas X IPS 1 SMA Negeri 1 Kerinci

\begin{tabular}{cccc}
\hline & & & \\
& Cukup aktif & $23,81 \%$ & 5 \\
& Aktif & $76,19 \%$ & 16 \\
\hline Antusias dalam mengikuti pembelajaran numbered head & Tidak aktif & $0 \%$ & 0 \\
together dengan media mind mapping. & Cukup aktif & $14,29 \%$ & $85,71 \%$ \\
\hline \multicolumn{1}{c}{ Rata - rata indikator aktivitas } & Aktif & 3 & 18 \\
\hline
\end{tabular}

Berdasarkan data di atas dapat diketahui dari indikator keaktifan siswa dalam belajar, indikator Visual Activity $80,95 \%$ atau 17 orang siswa dari 21 siswa aktif, Oral Activity 76,19\% atau 16 orang siswa dari 21 siswa aktif, Listening Activity $76,19 \%$ atau 16 orang siswa dari 21 siswa aktif, Writing Activity 76,19\% atau 16 orang siswa dari 21 orang siswa, Mental Activity $80,95 \%$ atau 17 orang siswa dari 21 orang siswa melaksanakan diskusi di kelas dengan baik dan antusias dalam mengikuti pembelajaran yang berlangsung menggunakan model pembelajaran kooperatif Numbered Head Together dengan media Mind Mapping, 85,71\% atau 18 dari 21 siswa, Emotional (antusias dalam melaksanakan pembelajaran dengan model pembelajaran Numbered Head Together dengan media Mind Mapping). Dari penjelasan di atas dapat di simpulkan bahwa akeaktifan belajar siswa pada siklus II mengalami peningkatan dari siklus I dan pembelajaran menggunakan model pembelajaran Numbered Head Together dengan media Mind Mapping, ini bisa dikatakan berhasil karena persentase aktivitas belajar lebih dari $75 \%$ yaitu dengan capaian rata-rata $79,36 \%$.

Tabel 6. Hasil Postes Siklus II

\begin{tabular}{ccc}
\hline No & Frekuensi & Post Test \\
\hline 1 & 2 & 90 \\
2 & 4 & 85 \\
3 & 9 & 80 \\
4 & 1 & 75 \\
5 & 5 & 65 \\
& Nilai Rata-Rata N $=21$ & $\mathbf{7 8}$
\end{tabular}

Tabel 8. Peningkatan Prestasi Belajar Ekonomi Siswa

\begin{tabular}{|c|c|c|c|c|c|c|c|}
\hline \multirow{2}{*}{ Siklus } & \multirow{2}{*}{ Nilai Terendah } & \multirow{2}{*}{$\begin{array}{c}\text { Nilai } \\
\text { Tertinggi }\end{array}$} & \multicolumn{2}{|c|}{ Jumlah Siswa } & \multicolumn{2}{|c|}{ Persentase } & \multirow{2}{*}{ Ket } \\
\hline & & & Belum Tuntas & Tuntas & $<75$ & $>75$ & \\
\hline I & 50 & 90 & 7 & 14 & $33 \%$ & $67 \%$ & Post test S. I \\
\hline II & 65 & 90 & 5 & 23 & $24 \%$ & $76 \%$ & Post test S.II \\
\hline
\end{tabular}

Sumber: Data Hasil Post test akhir siklus

Prestasi belajar siswa pada post test siklus I, siswa yang mencapai KKM adalah 14 orang siswa atau dengan persentase $67 \%$. Terjadinya peningkatan pada post test siklus II yaitu sebanyak $76 \%$. Penelitian ini membuktikan bahwa terjadinya peningkatan hasil belajar siswa dengan menggunakan model pembelajaran Kooperatif numbered head together dengan media mind
Tabel 7. Siswa yang sudah dan belum mencapai KKM Siklus II

\begin{tabular}{ccccc}
\hline \multirow{2}{*}{ Keterangan } & \multicolumn{2}{c}{ Jumlah siswa } & \multicolumn{2}{c}{ Persentase } \\
\cline { 2 - 5 } & $<70$ & $>70$ & $<70$ & $>70$ \\
\hline Post Test & 5 & 16 & $24 \%$ & $76 \%$ \\
\hline
\end{tabular}

Berdasarkan data pada kedua tabel di atas dapat disimpulkan bahwa rata-rata nilai post test pada siklus II adalah 78. Hal ini menunjukkan bahwa terjadi peningkatan yang signifikan terhadap hasil belajar siswa. Pada saat dilaksanakan post test, siswa yang mencapai KKM dengan persentase $76 \%$. Berdasarkan data siklus I dan siklus II, prestasi belajar siswa dengan menggunakan model pembelajaran kooperatif Numbered Head Together (NHT) dengan media Mind Mapping, ini bisa dikatakan berhasil karena persentase hasil belajar siswa lebih dari $75 \%$.

\section{Pembahasan}

Penelitian ini merupakan penelitian tindakan kelas yang menerapkan model pembelajaran kooperatif numbered head together dengan media mind mapping dengan tujuan untuk meningkatkan prestasi belajar ekonomi siswa. Penelitian ini dilaksanakan dengan empat tahapan yaitu perencanaan, pelaksanaan tindakan, pengamatan dan refleksi. Penelitian ini berlangsung dengan lancar dan baik. Peningkatan hasil belajar diukur menggunakan post test disetiap akhir siklus Berdasarkan post test dapat diketahui adanya peningkatan hasil belajar. Pengukuran prestasi belajar bertujuan untuk mengukur sejauh mana siswa telah menguasai materi yang telah diajarkan. Keberhasilan ini ditunjukkan berdasarkan nilai post test untuk hasil tiap siklus dapat dilihat pada tabel berikut ini : 
Eka Apriya Dewi, Peningkatan Keaktifan Belajar dan Hasil Belajar Siswa Melalui Model Pembelajaran Numbered Head Together dengan Media Mind Mapping Pada Mata Pelajaran Ekonomi Kelas X IPS 1 SMA Negeri 1 Kerinci

Tabel 9. Kategori Peningkatan Keaktifan Aktivitas Belajar Siswa

\begin{tabular}{|c|c|c|c|c|c|c|c|c|}
\hline \multirow{3}{*}{$\begin{array}{c}\text { Indikator Keaktifan } \\
\text { Belajar }\end{array}$} & \multicolumn{6}{|c|}{ Kategori Siswa Aktif } & \multirow{2}{*}{\multicolumn{2}{|c|}{$\begin{array}{c}\text { Persentase Peningkatan } \\
\text { Siklus I ke siklus II }\end{array}$}} \\
\hline & \multicolumn{2}{|c|}{ Pra Siklus } & \multicolumn{2}{|c|}{ Siklus I } & \multicolumn{2}{|c|}{ Siklus II } & & \\
\hline & $\mathbf{F}$ & $\%$ & $\mathbf{F}$ & $\%$ & $\mathbf{F}$ & $\%$ & $\mathbf{F}$ & $\%$ \\
\hline Visual Activity & 14 & $66,67 \%$ & 16 & $76,19 \%$ & 17 & $80,95 \%$ & 1 & $4,76 \%$ \\
\hline Oral Activity & 9 & $42,86 \%$ & 12 & $60 \%$ & 16 & $76,19 \%$ & 4 & $19,04 \%$ \\
\hline Listening Activity & 7 & $33,33 \%$ & 11 & $52,38 \%$ & 16 & $76,19 \%$ & 5 & $23,80 \%$ \\
\hline Writing Activity & 9 & $42,86 \%$ & 13 & $61,90 \%$ & 17 & $80,95 \%$ & 4 & $19,04 \%$ \\
\hline Mental Activity & 12 & $57,14 \%$ & 15 & $71,42 \%$ & 16 & $76,19 \%$ & 1 & $4,76 \%$ \\
\hline Emotional & 11 & $52,38 \%$ & 15 & $71,42 \%$ & 18 & $85,71 \%$ & 3 & $14,28 \%$ \\
\hline $\begin{array}{c}\text { \% Keaktifan Aktivitas } \\
\text { Belajar }\end{array}$ & & & & $65,55 \%$ & & $79,36 \%$ & $\begin{array}{c}\text { Rata-rata } \\
\text { peningkatan \% }\end{array}$ & $14,28 \%$ \\
\hline
\end{tabular}

Sumber: Data Primer yang diolah

Dari tabel di atas, terlihat bahwa terjadi peningkatkan keaktifan belajar siswa, pada siklus II pada indikator Visual Activity meningkat 4,76 \%, Oral Activity meningkat 19,04\%, Listening Activity meningkat 23,80\%, Writing Activity meningkat 19,04\%, Mental Activity meningkat 4,76\% dan Emotional (antusias dalam mengikuti pembelajaran dengan menggunakan model pembelajaran kooperatif numbered head together dengan media mind mapping ) meningkat 14,28\%. Rata-rata persentase peningkatan secara keseluruhan $14.28 \%$.

Sesuai dengan kriteria keberhasilan apabila ada peningkatan keaktifan belajar ekonomi dalam kegiatan pembelajaran di kelas dari siklus satu ke siklus dua maka Penelitian dengan menggunakan model pembelajaran Kooperatif numbered head together (NHT) ini bisa di kategorikan berhasil karena skor yang di capai sudah mencapai 79,36 ( $\geq 75)$.

\section{SIMPULAN}

Penerapan model pembelajaran Kooperatif numbered head together dengan media mind mapping dapat meningkatkan prestasi belajar siswa pada mata pelajaran ekonomi kelas X IPS 1 SMA Negeri 1 Kerinci. Hal ini dibuktikan dengan adanya peningkatan nilai dari siklus I dengan rata-rata sebesar 71 meningkat menjadi 78 di siklus II. Presentase ketuntasan belajar juga meningkat dari siklus I sebesar $67 \%$ meningkat menjadi $76 \%$ di siklus II. Pada Kategori Peningkatan Keaktifan Aktivitas Belajar Siswa juga menunjukkan peningkatan yang signifikan pada siklus I persentase keaktifan siswa baru mencapai 65,55\%, kemudian persentasenya meningkat di siklus II menjadi 79,36\% dengan rata-rata persentase 14,28\% Hal ini menunjukkan bahwa penerapan model pembelajaran Kooperatif numbered head together dengan media mind mapping dapat meningkatkan hasil belajar siswa pada mata pelajaran ekonomi kelas X IPS 1 SMA N 1 Kerinci. Guru sebaiknnya menerapkan model pembelajaran kooperatif numbered headtogether dengan media mind mapping pada kompetensi dasar teoritik yang lain sehingga dapat tercipta suasana pembelajaran yang efektif dan menyenangkan yang pada akhirnya dapat meningkatkan hasil belajar ekonomi siswa.

\section{DAFTAR PUSTAKA}

Abdurrahman, (2003), Pendidikan Bagi Anak Berkesulitan Belajar, Jakarta, Rhineka Cipta.

Agus Suprijono. (2012). Cooperative Learning TeoridanAplikasi PAIKEM.Yogyakarta: Pustaka Pelajar

Agus Suprijono. (2009). Cooperative Learning dan Aplikasi Paikem.Yogyakarta: Pustaka Belajar.

Darmadi, Hamid.2011.Metode Peneltian Pendidikan.Bandung:ALVABETA.cv

Dimyati dan Mudjiono. (2009). Belajar dan Pembelajaran. Jakarta: Rineka Cipta.

Fathurrohman, Muhammad dan Sulistyorini. 2012. Belajar dan Pembelajaran: Meningkatkan Mutu Pembelajaran Sesuai Standar Nasional. Yogyakarta: Teras.

Hamdani. 2011. Strategi Belajar Mengajar. Bandung: CV Pustaka Setia.

Huda, Miftahul. 2011. Cooperative Learning. Yogyakarta: PustakaBelajar.

Isjoni. 2009. Cooperative Learning. Bandung: Alfabeta.

Kunandar, D.R. (2008). Langkah Mudah Penelitian Tindakan Kelas Sebagai Pengembangan Profesi Guru. Jakarta: Raja Grafindo Persada.

Mulyasa, 2005 Implementasi Kurikulum 2004, Rosdakarya, Bandung, Mulyono

Nana Sudjana. (2004). Dasar-dasar Proses Belajar Mengajar. Bandung: Sinar Baru Algesindo.

Oemar Hamalik. 2001. Proses Belajar Mengajar, Jakarta: Bumi Aksara.

Rusman. 2011. Model-model Pembelajaran: Mengembangkan Profesionalisme Guru. Jakarta: Rajawali Pers.

Sardiman A.M, (2001), Interaksi dan Motivasi Belajar Mengajar, Jakarta: PT. Raja Grafindo Persada

Sugiyanto. 2010. Model PembelajaranInovatif. Surakarta. Yuma

Trianto. 2012. Mendesain Model Pembelajaran InovatifProgresif: Konsep, Landasan, dan Implementasinya pada Kurikulum Tingkat Satuan Pendidikan (KTSP). Jakarta: Kencana Prenada Media Group. 